\title{
PENGEMBANGAN MODEL CREATIVE PROBLEM SOLVING (CPS) UNTUK MENINGKATKAN KEMAMPUAN BERPIKIR REFLEKTIF SISWA
}

\author{
Ayu Devita Sari ${ }^{1}$, Sri Hastuti Noer ${ }^{2}$, Asmiati $^{3}$ \\ ${ }^{1,2}$ Program Pasca Sarjana Pendidikan Matematika, Universitas Lampung, Lampung \\ ${ }^{3}$ Program Pasca Sarjana Matematika, Universitas Lampung, Lampung \\ hastuti_noer@yahoo.com
}

\begin{abstract}
This study aims to develop a Creative Problem Solving model in the form of model books and learning tools to develop students' reflective thinking skills. The research used is a type of research development or R\&D (research and development). However, research is limited to the expert test stage, so this development stage starts from preliminary studies, preparation of learning development, expert validation. The subjects of this study were 2 teachers and 2 lecturers. This Research Instrument is a validation sheet for experts and practitioners. The results of this study are (1) creative problem solving (CPS) model design, (2) learning devices in the form of syllabus, Learning Implementation Plan (RPP) and Student Worksheet (LKPD) with the topic of SPLTV operation class X SMA Negeri 15 Bandar Lampung odd semester. Validation results include: model development design assessment score of $92.5 \%$ by model experts and $95 \%$ for material experts; Syllabus scores of $98 \%$ for material experts 1 and $94 \%$ for material experts 2; RPP score of $97 \%$ for material experts 1 and $95 \%$ for material experts 2; LKPD scores of $91.67 \%$ for material experts 1 and $94.44 \%$ for material experts 2; Media score is $95 \%$ for media experts and $94 \%$ for material experts. The results of the validation of the experts showed that the development of the Creative Problem Solving model and learning tools was feasible to use and implemented after meeting valid and practical criteria. This can be seen from the results of the validator's assessment score which has valid criteria and very practical categories. Based on the assessment of experts, then theoretically the product development of Creative Problem Solving Model (CPS) can be used to improve the reflective thinking of students.
\end{abstract}

Keywords: Creative Problem Solving (CPS), Reflective.

\begin{abstract}
Abstrak
Penelitian ini bertujuan untuk mengembangkan model Creative Problem Solving berupa buku model dan perangkat pembelajaran untuk mengembangkan kemampuan berpikir reflektif siswa. Penelitian yang digunakan adalah jenis penelitian pengembangan atau R\&D ( reseacrch and development). Namun penelitian dibatasi sampai pada tahap uji ahli, sehingga tahapan pengembangan ini dimulai dari studi pendahuluan, penyusunan pengembangan pembelajaran, validasi ahli. Subjek penelitian ini adalah 2 orang guru dan 2 orang dosen. Instrumen Penelitian ini berupa lembar validasi untuk ahli dan praktisi. Hasil penelitian ini adalah (1) desain model Creative Problem Solving (CPS), (2) perangkat pembelajaran berupa silabus, Rencana Pelaksanaan Pembelajaran (RPP) dan Lembar Kerja Peserta Didik (LKPD) dengan topik operasi SPLTV kelas X SMA Negeri 15 Bandar Lampung semester ganjil. Adapun hasil validasi meliputi: skor penilaian desain pengembangan model sebesar $92,5 \%$ oleh ahli model dan $95 \%$ untuk ahli materi; skor Silabus sebesar $98 \%$ untuk ahli materi 1 dan $94 \%$ untuk ahli materi 2; skor RPP sebesar 97\% untuk ahli materi 1 dan $95 \%$ untuk ahli materi 2; Skor LKPD sebesar 91,67\% untuk ahli materi 1 dan 94,44\% untuk ahli materi 2; Skor Media sebesar 95\% untuk ahli media dan $94 \%$ untuk ahli materi. Hasil validasi para ahli diperoleh bahwa pengembangan model Creative Problem Solving dan perangkat pembelajaran layak digunakan dan diimplementasikan setelah memenuhi kriteria valid dan praktis. Hal ini dapat dilihat dari hasil skor penilaian validator yang memiliki kriteria valid dan kategori sangat praktis. Berdasarkan penilaian para ahli, maka secara teoritis produk pengembangan Model Creative Problem Solving (CPS) dapat digunakan untuk meningkatkan Keteramplilan berpikir reflektif siswa.
\end{abstract}

Kata kunci: Creative Problem Solving (CPS), Reflektif

\section{PENDAHULUAN}

Pendidikan adalah hal yang penting bagi setiap manusia karena dengan pendidikan manusia dapat mengembangkan potensi dirinya untuk mencapai kesejahteraan hidup. Salah satu tahap penting dalam pendidikan adalah pembelajaran dimana dalam proses pembelajaran terjadi interaksi antara 
guru dan siswa serta siswa dengan siswa. Interaksi dalam proses belajar tidak hanya sekedar menyampaikan materi pelajaran melainkan juga nilai dan sikap pada diri siswa yang sedang belajar.

Masalah utama dalam pembelajaran pada pendidikan formal (sekolah) adalah masih rendahnya daya serap siswa, termasuk dalam pembelajaran matematika. Pembelajaran matematika tidak hanya mengharuskan siswa sekedar mengerti materi yang dipelajari saat itu, tapi juga belajar dengan pemahaman dan aktif membangun pengetahuan baru dari pengalaman dan pengetahuan yang dimiliki sebelumnya agar pembelajarannya lebih bermakna.

Sabandar (2013) berpendapat bahwa pembelajaran matematika di sekolah tidak hanya bertujuan agar siswa memahami materi matematika yang diajarkan. Tujuan - tujuan utama lain, misalnya kemampuan penalaran matematika, komunikasi matematika, koneksi matematika, representasi matematika dan pemecahan masalah matematika, serta perilaku tertentu yang harus siswa peroleh setelah ia mempelajari matematika.

Pemecahan masalah menuntut pelibatan kemampuan berpikir tingkat tinggi (High-Order Thinking Skills/HOTS). HOTS merupakan tujuan utama dalam pembelajaran matematika (Gokhale, 1996: 1). Salah satu kemampuan berpikir matematika yang baik untuk dikembangkan dalam pembelajaran adalah kemampuan berpikir reflektif.

Menurut Dewey dalam Noer (2010) bahwa berpikir reflektif adalah salah satu kemampuan berpikir tingkat tinggi. Berpikir reflektif membentuk siswa untuk menghubungkan pengetahuan terdahulu untuk menyelesaikan permasalahan yang saling berkaitan dan tersusun dalam proses penyelesaiannya dengan mengungkapkan ide dan gagasan yang saling berhubungan dalam pikiran siswa. Hal ini selaras dengan pendapat Rasyid (2017) berpikir reflektif adalah aktivitas mental seseorang untuk mengidentifikasi masalah dan memecahkan masalah dengan menggunakan pengetahuan dan pengalaman yang berkaitan dengan masalah yang dihadapi, dan melakukan komponen-komponen berpikir reflektif, yaitu reacting, elaborating dan contemplating.

Pemecahan masalah dalam berpikir reflektif menekankan pada proses dan tujuan akhir yang ingin dicapai sebelum mendapatkan hasil akhir. Menurut Gurol (2011) berpikir reflektif merupakan proses kegiatan terarah dan tepat saat individu dapat menyadari, menganalisis, mengevaluasi, dan memotivasi proses belajarnya sendiri. Penelitian mengenai kemampuan berpikir reflektif dalam memecahkan masalah sendiri telah banyak dilakukan,. Selain itu, Nindiasari (2014) mengungkapkan bahwa berpikir reflektif merupakan kemampuan untuk menginterpretasi suatu kasus berdasarkan konsep matematika yang terlibat, mengevaluasi kebenaran suatu argument, menganalisis dan mengklarifikasi jawaban, menggeneralisasi, serta membedakan antara data yang relevan dan tidak relevan.

Berdasarkan uraian pendapat tersebut, dapat disimpulkan bahwa berpikir reflektif merupakan bagian dari kemampuan berpikir tingkat tinggi yang ada dalam pembelajaran matematika dan menekankan pada proses dengan menghubungkan pengetahuan yang telah dimiliki dan yang sedang 
Pengembangan Model Creative Problem Solving (CPS) Untuk Meningkatkan Kemampuan Berpikir Reflektif Siswa, Ayu Devita Sari, Sri Hastuti Noer, Asmiati

dipelajari dalam menganalisa masalah, mengevaluasi, menyimpulkan dan memutuskan penyelesaian terbaik terhadap masalah yang diberikan.

Adapun indikator kemampuan reflektif matematis menurut Noer (2010) meliputi 3 fase yaitu:

1. Reacting (berpikir reflektif untuk aksi)

2. Comparing (berpikir reflektif untuk evaluasi)

3. Contemplating (berpikir reflektif untuk inquiri kritis)

Sehingga, berdasarkan pendapat di atas maka indikator kemampuan berpikir reflektif matematis yang digunakan dalam penelitian ini dijabarkan pada Tabel 1 berikut.

\section{Tabel 1}

Indikator Kemampuan Berpikir Reflektif Matematis

\begin{tabular}{|l|l|}
\hline Indikator & Pengertian \\
\hline Reacting & $\begin{array}{l}\text { Berpikir reflektif untuk aksi. Menuliskan sifat - sifat yang } \\
\text { dimiliki oleh situasi kemudian menjawab permasalahan. }\end{array}$ \\
\hline Comparing & $\begin{array}{l}\text { Berpikir reflektif untuk evaluasi. Membandingkan suatu reaksi } \\
\text { dengan prinsip umum atau teori dengan memberi alasan kenapa } \\
\text { memilih tindakan tersebut. }\end{array}$ \\
\hline Contemplating & $\begin{array}{l}\text { Berpikir reflektif untuk inkuiri kritis. Mengonfirmasi jawaban } \\
\text { berdasarkan situasi masalah, mempertentangkan jawaban } \\
\text { dengan jawaban lain kemudian merekonstruksi situasi - situasi. }\end{array}$ \\
\hline
\end{tabular}

Noer (2010)

Kemampuan berpikir reflektif matematis ini sangat dibutuhkan siswa dalam belajar matematika. Siswa seringkali menemukan soal yang tidak dengan segera dapat dicari solusinya, sementara siswa dituntut untuk dapat menyelesaikan soal tersebut. Untuk itu, siswa perlu berpikir atau bernalar, menduga atau memprediksi, mencari rumusan yang sederhana, baru kemudian membuktikan kebenarannya. Siswa perlu memiliki kemampuan berpikir, untuk menemukan cara tepat menyelesaikan masalah matematis yang dihadapinya. Hal ini diperkuat dengan ungkapan Sabandar (2013) bahwa kemampuan berpikir reflektif dalam matematika akan berkesempatan dimunculkan dan dikembangkan ketika siswa sedang berada dalam proses intens pemecahan masalah.

Akan tetapi kenyataan dilapangan menunjukkan bahwa peningkatan kemampuan berpikir reflektif belum mendapatkan perhatian khusus. Sampai saat ini perhatian pengembangan kemampuan berpikir reflektif siswa relatif rendah.

Berdasarkan pengamatan dan wawancara terhadap guru dan beberapa siswa SMA Negeri 15 Bandar Lampung dari kelas X pada tanggal 20 Februari 2020 tahun ajaran 2018/2019 menunjukkan bahwa guru terbiasa menjelaskan secara langsung konsep - konsep yang sudah ada dan kurang melatih siswa untuk membangun pengetahuan secara mandiri. Kecenderungan pembelajaran berpusat pada guru, siswa cenderung pasif dalam menerima pelajaran matematika, siswa masih kesulitan dalam mengidentifikas masalah konstektual (kehidupan sehari-hari) ke dalam bentuk model matematika, siswa kesulitan dalam menentukan strategi yang digunakan dalam menjawab soal matematika, dan siswa kesulitan dalam mengerjakan soal yang memerlukan kemampuan berpikir 
tingkat tinggi.

Sementara itu, kenyataan juga menunjuukkan bahwa guru jarang menggunakan model pembelajaran khusus, buku siswa dan buku guru yang berasal dari bantuan pemerintah sehingga tidak jarang bahan ajar yang digunakan guru tidak sesuai dengan karakateristik siswa dan tujuan pembelajaran. Oleh sebab itu berdasarkan pendapat di atas model pembelajaran yang tidak sesuai tersebut kurang memfasilitisai siswa dalam mengembangkan kemampuan berpikir reflektif siswa.

Menyikapi permasalahan yang terjadi di lapangan yaitu dalam proses pembelajaran matematika di sekolah, terutama yang berkaitan dengan pentingnya kemampuan berpikir reflektif siswa yang akhirnya mengakibatkan rendahnya hasil belajar matematika. Perlu adanya solusi berupa model pembelajaran yang dapat mengakomodasi peningkatan kemampuan berpikir reflektif. Model pembelajaran berdasarkan masalah dianggap cocok untuk mengatasi masalah ini.

Menyadari pentingnya kemampuan berpikir reflektif matematika siswa, guru harus mengupayakan pembelajaran yang menarik. Hal ini, sebaiknya guru harus membuat sesuatu trik di mana matematika itu dapat dikemas menjadi pelajaran yang menarik dan mudah dimengerti. Salah satu alternatif yang dapat dilakukan adalah dengan model pembelajaran yang tepat.

Penggunaan model pembelajaran yang tepat dapat mengefektifkan dan memudahkan proses belajar mengajar. Hal ini menunjukkan bahwa dalam pembelajaran matematika guru harus menggunakan model pembelajaran yang tepat dan disesuaikan dengan kondisi siswa agar dalam proses pembelajaran siswa lebih memahami materi dan lebih berkesan dengan pembelajaran yang telah disampaikan serta siswa akan lebih mengingat hal-hal yang dipelajari.

Salah satu alternatif pembelajaran yang memungkinkan dapat mengoptimalkan kemampuan berpikir reflektif siswa adalah model pembelajaran Creative Problem Solving (CPS). Menurut Pepkin dalam Saminanto (2011), model Creative Problem Solving (CPS) adalah suatu model pembelajaran yang melakukan pemusatan pada pengajaran dan kemampuan pemecahan masalah yang diikuti dengan penguatan kemampuan. Model pembelajaran Creative Problem Solving (CPS) dapat mendorong siswa aktif sehingga dapat mengoptimalkan kemampuan berpikir reflektif siswa. Model pembelajaran Creative Problem Solving (CPS) memiliki keunggulan yaitu dalam pembelajarannya melatih siswa untuk bisa berpikir logis, terampil, dan kreatif.

Model CPS menurut Mayasari (2013) mampu membuat pembelajaran berlangsung lebih menyenangkan, dapat membangkitkan motivasi siswa dan mendorong siswa membangun pengetahuannya sendiri. Sedangngkan menurut Daties (2010) ada beberapa alasan memilih model CPS dalam pembelajaran. Pertama, model pembelajaran CPS termasuk kedalam model pembelajaran dengan pendekatan konstruktivistik, dimana yang menjadi pusat pembelajaran adalah siswa (student centered) sehingga model tersebut dianggap mampu mengaktifkan siswa. Dengan demikian akan diperoleh hasil pembelajaran yang maksimum. Kedua, model pembelajaran CPS dapat digunakan pada siswa dengan kemampuan intelektual beragam, sehingga tidak perlu memisahkan antara anak yang cerdas dan anak yang memiliki kemampuan intelektual menengah ke bawah. Sehingga mereka 
Pengembangan Model Creative Problem Solving (CPS) Untuk Meningkatkan Kemampuan Berpikir Reflektif Siswa, Ayu Devita Sari, Sri Hastuti Noer, Asmiati

tidak merasa "terpinggirkan". Ketiga, model pembelajaran CPS tidak hanya terbatas pada tingkat pengenalan, pemahaman dan penerapan sebuah informasi, melainkan juga melatih siswa untuk dapat menganalisis suatu masalah dan memecahkannya. Keempat, model pembelajaran CPS mudah dipahami dan diterapkan dalam setiap jenjang pendidikan dan tiap materi pembelajaran.

Berdasarkan pendapat para ahli diatas maka model pembelajaran Creative Problem Solving (CPS) adalah suatu model pembelajaran yang melakukan pemusatan pada pengajaran dan kemampuann pemecahan masalah yang diikuti dengan penguatan kemampuan. Ketika dihadapkan dengan suatu pertanyaan, siswa dapat melakukan kemampuan memecahkan masalah untuk memilih dan mengembangkan tanggapannya. Tidak hanya dengan cara menghapal tanpa berpikir, kemampuan memecahkan masalah memperluas proses berpikir.

Model CPS memiliki beberapa langkah pada implementasinya dalam proses pembelajaran. Menurut Aris (2014) mengemukakan bahwa langkah-langkah model Creative Problem Solving adalah sebagai berikut:

a. Klarifikasi masalah

Klarifikasi masalah meliputi pemberian pembelajaran kepada siswa tentang masalah yang diajukan agar siswa dapat memehami tentang penyelesaian seperti apa yang diharapkan.

b. Pengungkapan pendapat

Pada tahap ini siswa dibataskan untuk mengungkapkan pendapat tentang berbagai macam strategi penyelesaian masalah .

c. Evaluasi dan pemilihan

Pada tahap Evaluasi dan pemilihan, setiap kelompok mendiskusikan pendapat - pendapat atau strategi-strategi mana yang cocok untuk menyelesaikan masalah.

d. Implementasi

Pada tahap ini siswa menentukan strategi mana dapat diambil untuk menyelesaikan masalah.

Kemudian menerapkannya sampai menemukan penyelesaian dari masalah tersebut.

Adapun keunggulan Model Creative Problem Solving Menurut Aris (2014) antara lain, (1) melatih siswa untuk mendisain suatu penemuan, (2) siswa akan lebih berpikir dan bertindak kreatif, (3) siswa dapat memecahkan masalah yang dihadapi secara realistis, (4) siswa dapat mengidentifikasi dan melakukan penyelidikan,dan (5) siswa dapat menafsirkan dan mengevaluasi hasil pengamatan.

Model creative problem solving dapat dikatakan pembelajaran yang tercakup dalam pembelajaran konstruktivisme. Inti dari model creative problem solving adalah siswa dapat aktif dalam proses pembelajaran dengan menyelesaikan suatu permasalahan dan menyimpulkan dengan cara yang terbaik. Dasar dari masalah model creative problem solving yaitu permasalahan yang berkaitan dengan kehidupan nyata. Sehingga siswa akan terdorong untuk menemukan alternatif solusi dari masalah yang harus dipecahkan. Hal ini selaras dengan pendapat Noer (2009) bahwa masalah dimunculkan sedemikian hingga siswa perlu menginterpretasi masalah, mengumpulkan informasi yang diperlukan, 
mengevaluasi alternatif solusi, dan mempresentasikan solusinya.

Berdasarkan beberapa teori yang telah dikemukakan oleh para ahli, sehingga dapat disumpulkan bahwa model creative problem solving dapat menjadi alternatif untuk meningkatkan kemampuan berpikir reflektif siswa

\section{METODE}

Penelitian ini menghasilkan pengembangan model pembelajaran creative problem solving yang di dalamnya mencakup perangkat pembelajaran antara lain: silabus, Rencana Pelaksanaan Pembelajaran (RPP) dan Lembar Kerja Peserta Didik (LKPD). Penelitian pengembangan Langkah-langkah penelitian pengembangan sebagai berikut: (1)Research and information collecting (studi pendahuluan), (2) Planning (merencanakan penelitian), (3) Develop preliminary from of product (mengembangan desain), (4) Preliminary field testing (uji coba lapangan awal), (5) Main product revision (revisi hasil uji coba), (6) Main field test (uji lapangan produk utama), (7) Operational product revision (revisi produk), (8) Operational field testing (uji coba lapangan secara luas), (9) Final product revision (revisi produk final), (10)Dissemination and implementation (desiminasi dan implemnetasi produk). Penelitian pengembangan ini bersifat terbatas, tahapan $R \& D$ hanya dilakukan hingga langkah 3. Develop preliminary from produk atau mengembangkan desain. Pembatasan tahapan R\&D ini dilakukan karena merujuk pada surat edaran Dekan FKIP Universitas Lampung nomor : 1980/UN26.13/PP.03.02/2020 Tentang Penyelesaian Penelitian Pengembangan terbatas sampai tahap validasi ahli dan dilaksanakan sesuai protokol darurat pencegahan penyebaran virus covid-19 dan mengingat keterbatasan waktu dalam menyelesaikan penelitian pengembangan ini.

Subjek pada penelitian ini adalah guru dan dosen sebagai ahli pembelajaran. Ahli berperan untuk memperoleh data mengenai validasi isi perangkat pembelajaran yang dikembangkan. Sedangkan objek pada penelitian ini adalah kualitas perangkat pembelajaran yang terdiri dari silabus, RPP, dan LKPD dengan materi SPLTV. Data yang dikumpulkan dalam penelitian ini berupa data kualitatif dan data kuantitatif. Data kualitatif didapatkan melalui hasil review dari ahli isi dan ahli pembelajaran berupa tanggapan, masukan, saran dan kritik. Sedangkan data kuantitatif didapat dari instrumen validasi perangkat pembelajaran oleh para ahli.

Teknik pengumpulan data yang dilakukan dalam penelitian ini menggunakan, wawancara, obsrevasi, dan angket. Instrumen angket berupa pernyataan skala likert dengan empat pilihan jawaban yaitu 1 (sangat kurang); 2 (kurang); 3 (baik); 4 (sangat baik). Adapun rumus yang digunakan untuk menentukan kevalidan produk adalah sebagai berikut:

$$
P=\frac{\sum x i}{\sum x} \times 100 \%
$$

Keterangan :

$P \quad:$ Persentase penilaian

$\sum x_{i} \quad$ : Jumlah yang diperoleh 
Pengembangan Model Creative Problem Solving (CPS) Untuk Meningkatkan Kemampuan Berpikir Reflektif Siswa, Ayu Devita Sari, Sri Hastuti Noer, Asmiati

$\sum x \quad$ Jumlah maksimal

Adapaun kriteria Tingkat Kevalidan Produk dapat dilihat pada tabel berikut:

Tabel 2.

Kriteria Tingkat Kevalidan Produk

\begin{tabular}{ccc}
\hline No. & Persentase $(\%)$ & Kriteria Validasi \\
\hline 1 & $76-100$ & Valid \\
2 & $56-75$ & Cukup Valid \\
3 & $40-55$ & Kurang Valid \\
4 & $0-39$ & Tidak Valid \\
\hline
\end{tabular}

Sebuah produk yang dikembangkan akan dikatakan layak untuk digunakan apabila persentase yang diperoleh $\geq 56 \%$ dengan kategori minimal cukup valid.

\section{HASIL}

Hasil dari penelitian ini berupa produk yaitu draf model Creative Problem Solving (CPS) yang berorientasi meningkatkan Ketaramplilan berpikir reflektif; silabus, RPP, dan LKPD Tema pada topik SPLTV. Pengembangan yang dilakukan berdasarkan langkah-langkah pengembangan Borg and Gall sampai pada tahap pengembangan.

Penelitian diawali dengan Research and Information Collectin (studi pendahuluan) yang terdiri dari observasi, wawancara, dan studi kesulitan siswa yang dilaksanakan di kelas X SMA negeri 15 Bandar Lampung. Berdasarkan pengamatan dan wawancara terhadap guru dan beberapa siswa SMA Negeri 15 Bandar Lampung dari kelas X pada tanggal 20 Februari 2020 tahun ajaran 2018/2019 menunjukkan data sebagai berikut:

1) guru terbiasa menjelaskan secara langsung konsep - konsep yang sudah ada dan kurang melatih siswa untuk membangun pengetahuan secara mandiri.

2) Kecenderungan pembelajaran berpusat pada guru, siswa cenderung pasif dalam menerima pelajaran matematika

3) Siswa masih kesulitan dalam mengidentifikas masalah konstektual (kehidupan sehari- hari) ke dalam bentuk model matematika

4) Siswa kesulitan dalam menentukan strategi yang digunakan dalam menjawab soal matematika,

5) Siswa kesulitan dalam mengerjakan soal yang memerlukan kemampuan berpikir tingkat tinggi.

6) Guru jarang menggunakan model pembelajaran khusus

Selanjutnya peneliti mengumpulkan sumber ajar yang digubakan oleh guru. Adapaun buku siswa dan buku guru yang yang digunakan merupakan buku yang berasal dari bantuan pemerintah, yaitu buku matematika kurikulum 2013. Selanjutnya peneliti mencari beberapa penelitian yang relevan sebagai acuan penyusunan LKPD dalam pembelajaran model Creative Problem Solving (CPS). Selain 
itu, menganalisis Standar Kompetensi (SK) dan Kompetensi Dasar (KD) materi pembelajaran serta mengkaji penelitian yang relevan sebagai tindakan Studi literatur. Adapun materi ajar yang ditentukan dalam penelitian adalah operasi aljabar.

Tahap selanjutnya adalah Planning, yaitu peneliti melakukan perencanaan penyusunan pengembangan. Pengembangan yang akan dilakukan meliputi pengembangan sintak model Creative Problem Solving (CPS) beserta perangkat pendukung berupa silabus, RPP, dan LKPD.

Tahap selanjutnya adalah Develop Preliminary of Product yaitu membuat rancangan model pembelajaran berbentuk darf model Creative Problem Solving (CPS) yang berorientasi pada kemampuan berpikir kritis. Setelah dilakukan penyusunan pengembangan model beserta perangkat pendukung, selanjutnya dilakukan validasi oleh ahli. Tujuannya untuk menilai instrumen-instrumen agar lebih efektif atau mengevaluasi kemungkinan kekurangan yang terdapat pada produk. Validasi terdiri dari validasi model pembelajaran, validasi RPP, dan validasi LKPD. Validasi dilakukan berdasarkan instrumen penilaian validasi model, validasi materi, dan validasi media.

\section{Validasi Model}

Validasi model pembelajaran dilakukan oleh ahli pembelajaran, Bapak Drs. H. Sukron, M.Pd dari staf pengawas bidang pendidikan madrasah Kemenag Lampung. Adapun data hasil validasi model Creative Problem Solving (CPS) berbasis metakognitif dirangkum pada Tabel 4 berikut:

Tabel 3.

Skor dan Kriteria Hasil Validasi Desain Model Creative Problem Solving (CPS) oleh ahli Model

\begin{tabular}{|c|c|c|c|}
\hline Nama Validator & No. Butir Penilaian & Penilaian & Skor yang Diperoleh \\
\hline \multirow{4}{*}{$\begin{array}{c}\text { Drs. H. Sukron, } \\
\text { M.Pd }\end{array}$} & 1 & SB & 4 \\
\cline { 2 - 4 } & 2 & SB & 4 \\
\cline { 2 - 4 } & 3 & SB & 4 \\
\cline { 2 - 4 } & 4 & SB & 4 \\
\cline { 2 - 4 } & 5 & SB & 4 \\
\cline { 2 - 4 } & 6 & SB & 3 \\
\cline { 2 - 4 } & 7 & B & 3 \\
\cline { 2 - 4 } & 8 & SB & 4 \\
\hline & 10 & & 37 \\
\hline Jumlah & \\
\hline
\end{tabular}

Berdasarkan Tabel 3. hasil validasi desain model Creative Problem Solving (CPS) dipeoleh persentase $92,5 \%$ dengan kriteria valid. Selanjutnya dilakukan revisi berdasarkan saran dan masukan dari ahli.

Adapun saran dari validator adalah untuk memperjelas terkait dampak penggiring dan rangkaian intruksional draf tiap tahapan pembelajaran. Hasil revisi yang telah dilakukan, selanjutnya 
Pengembangan Model Creative Problem Solving (CPS) Untuk Meningkatkan Kemampuan Berpikir Reflektif Siswa, Ayu Devita Sari, Sri Hastuti Noer, Asmiati

dikonsultasikan kembali kepada ahli tersebut sampai diperoleh desain model Creative Problem Solving (CPS) dikatakan valid dan layak digunakan. Adapun desain sintak model Creative Problem

Solving (CPS) yang berorientasi pada kemampuan berpikir reflektif dijabarkan pada tabel berikut:

Tabel 4.

Tahapan Model Creative Problem Solving (CPS)

\begin{tabular}{|c|c|c|}
\hline Fase & Tahapan Model CPS & $\begin{array}{l}\text { Tahapan Model CPS yang telah } \\
\text { dikembangkan berorientasi pada } \\
\text { kemampuanberpikir reflektif }\end{array}$ \\
\hline $\begin{array}{l}\text { Klarifikasi } \\
\text { Masalah }\end{array}$ & $\begin{array}{l}\text { Klarifikasi } \text { masalah meliputi } \\
\text { pemberian pembelajaran kepada } \\
\text { siswa tentang masalah yang } \\
\text { diajukan agar siswa dapat } \\
\text { memehami tentang penyelesaian } \\
\text { seperti apa yang diharapkan. }\end{array}$ & $\begin{array}{l}\text { guru akan membimbing siswa untuk } \\
\text { memulai pembelajaran dengan } \\
\text { memberikan pertanyaan atau } \\
\text { permasalahan tentang materi pelajaran } \\
\text { yang akan dipelajari siswa. Yang harus } \\
\text { dilakukan siswa adalah membaca soal } \\
\text { dengan seksama sehingga benar - benar } \\
\text { dimengerti arti dari semua kata dalam } \\
\text { soal. Buat tanda khusus untuk beberapa } \\
\text { istilah yang digunakan kalimat dalam } \\
\text { soal. Dalam proses pembelajaran ini, } \\
\text { siswa diharapkan dapat memahami } \\
\text { masalah dengan menuliskan semua hal } \\
\text { apa yang diketahui dan yang tidak } \\
\text { diketahui dari masalah tersebut. }\end{array}$ \\
\hline $\begin{array}{l}\text { Pengungkapan } \\
\text { Pendapat }\end{array}$ & $\begin{array}{l}\text { Pada tahap ini siswa dibataskan } \\
\text { untuk mengungkapkan pendapat } \\
\text { tentang berbagai macam strategi } \\
\text { penyelesaian masalah. }\end{array}$ & $\begin{array}{l}\text { siswa telah dibagi kedalam beberapa } \\
\text { kelompok, kemudian } \\
\text { mendiskusikan dan membrainstorming } \\
\text { tujuan atau sasaran yang dapat digunakan } \\
\text { dalam meyelesaikan masalah yang } \\
\text { diberikan. Siswa dibebaskan untuk } \\
\text { mengungkapkan pendapat tentang } \\
\text { berbagai macam strategi penyelesaian } \\
\text { masalah. }\end{array}$ \\
\hline $\begin{array}{l}\text { Evaluasi atau } \\
\text { Pemilihan }\end{array}$ & $\begin{array}{l}\text { Pada tahap Evaluasi dan pemilihan } \\
\text {, setiap kelompok mendiskusikan } \\
\text { pendapat - pendapat atau strategi- } \\
\text { strategi mana yang cocok untuk } \\
\text { menyelesaikan masalah. }\end{array}$ & $\begin{array}{l}\text { Setiap kelompok mendiskusikan } \\
\text { pendapat-pendapat atau strategi-strategi } \\
\text { apa yang cocok untuk menyelesaikan } \\
\text { masalah. Dalam proses ini, siswa dapat } \\
\text { menjalankan rencana/ strategi yang telah } \\
\text { disusunnya. Kemudian diperiksa setiap } \\
\text { langkah yang telah disusun apakah sudah } \\
\text { benar? bagaimana membuktikan bahwa } \\
\text { langkah yang ditempuh sudah benar ?. } \\
\text { siswa akan fokus terhadap suatu tingkatan } \\
\text { pribadi dalam proses-proses seperti } \\
\text { menguraikan, menginformasikan, } \\
\text { mempertimbangkan, dan merekonstruksi } \\
\text { situasi atau masalah (comtemplating). }\end{array}$ \\
\hline Implementasi & Pada tahap ini siswa menentukan & $\begin{array}{l}\text { siswa menentukan strategi yang dapat } \\
\text { diambil untuk menyelesaikan masalah. }\end{array}$ \\
\hline
\end{tabular}




\begin{tabular}{|l|l|l|}
\hline strategi mana dapat diambil untuk & Kemudian menerapkannya sampai \\
menyelesaikan masalah. Kemudian & menemukan penyelesaian dari masalah \\
menerapkannya sampai & $\begin{array}{l}\text { tersebut. Setelah penarikan kesimpulan, } \\
\text { dilakukan tes untuk menguji kemampuan }\end{array}$ \\
menemukan penyelesaian dari & $\begin{array}{l}\text { berpikir reflektif siswa. Kemudian } \\
\text { masalah tersebut. }\end{array}$ & $\begin{array}{l}\text { dilakuan refleksi diri untuk mengetahui } \\
\text { pemahaman siswa lebih mendalam, } \\
\text { kekuatan dan kelemahan siswa. }\end{array}$ \\
\hline
\end{tabular}

\section{Validasi Silabus}

Adapun Validasi Silabus dilakukan oleh Ahli materi, yaitu bapak Bapak Drs. H. Sukron, M.Pd dari staf pengawas bidang pendidikan madrasah Kemenag Lampung dan Ibu Avissa Purnama Yanti, M.Pd dari Universitas Islam Negri Raden Intan Lampung. Adapun rekapitulasi hasil penilaian validator ahli materi terhadap Silabus diperoleh sebagai berikut:

\section{Tabel 5}

Skor dan Kategori Hasil Validasi Silabus oleh ahli 1

\begin{tabular}{|c|c|c|c|}
\hline Nama Validator & No. Butir Penilaian & Penilaian & Skor yang Diperoleh \\
\hline \multirow{13}{*}{$\begin{array}{l}\text { Drs. H. Sukron, } \\
\text { M.Pd }\end{array}$} & 1 & SB & 4 \\
\hline & 2 & SB & 4 \\
\hline & 3 & SB & 4 \\
\hline & 4 & SB & 4 \\
\hline & 5 & SB & 4 \\
\hline & 6 & SB & 4 \\
\hline & 7 & SB & 4 \\
\hline & 8 & SB & 4 \\
\hline & 9 & SB & 4 \\
\hline & 10 & $\mathrm{~B}$ & 3 \\
\hline & 11 & SB & 4 \\
\hline & 12 & SB & 4 \\
\hline & 13 & SB & 4 \\
\hline \multicolumn{3}{|c|}{ Jumlah } & 51 \\
\hline \multicolumn{3}{|c|}{ Presentase Tingkat Kevalidan } & $98 \%$ \\
\hline \multicolumn{3}{|c|}{ Kriteria Valid } & Valid \\
\hline
\end{tabular}

\section{Tabel 6}

Skor dan Kategori Hasil Validasi Silabus oleh ahli 2

\begin{tabular}{|c|c|c|c|}
\hline Nama Validator & No. Butir Penilaian & Penilaian & Skor yang Diperoleh \\
\hline \multirow{4}{*}{$\begin{array}{c}\text { Avissa Purnama } \\
\text { Yanti, M.Pd }\end{array}$} & 1 & SB & 4 \\
\cline { 2 - 4 } & 2 & SB & 4 \\
\cline { 2 - 4 } & 3 & B & 3 \\
\cline { 2 - 4 } & 4 & SB & 4 \\
\cline { 2 - 4 } & 5 & SB & 4 \\
\cline { 2 - 4 } & 6 & SB & 4 \\
\cline { 2 - 4 } & 7 & SB & 4 \\
\cline { 2 - 4 } & 8 & SB & 3 \\
\hline
\end{tabular}


Pengembangan Model Creative Problem Solving (CPS) Untuk Meningkatkan Kemampuan Berpikir Reflektif Siswa, Ayu Devita Sari, Sri Hastuti Noer, Asmiati

\begin{tabular}{|c|c|c|c|}
\hline \multirow{2}{*}{} & 11 & SB & 4 \\
\cline { 2 - 4 } & 12 & B & 3 \\
\cline { 2 - 3 } & 13 & SB & 4 \\
\hline Jumlah & 49 \\
\hline Presentase Tingkat Kevalidan & $94 \%$ \\
\hline Kriteria Valid & Valid \\
\hline
\end{tabular}

Berdasarkan Tabel 5 dan 6 di atas, secara keseluruhan Silabus memperoleh skor 98\% dan 94\% dan memenuhi kriteria valid sehingga dapat digunakan dengan revisi. Hasil revisi yang telah dilakukan, selanjutnya dikonsultasikan kembali kepada ahli sampai diperoleh perangkat pembelajaran yang dikatakan layak dan dapat digunakan. Setelah dilakukan revisi, perangkat pembelajarannya kembali dinilai oleh masing-masing ahli.

\section{Validasi RPP}

Validasi RPP dilakukan oleh Ahli materi, yaitu bapak Bapak Drs. H. Sukron, M.Pd dari staf pengawas bidang pendidikan madrasah Kemenag Lampung dan Ibu Avissa Purnama Yanti, M.Pd dari Universitas Islam Negri Raden Intan Lampung. Adapun rekapitulasi hasil penilaian validator ahli materi terhadap RPP diperoleh sebagai berikut:

\section{Tabel 7}

Skor dan Kategori Hasil Validasi RPP oleh ahli 1

\begin{tabular}{|c|c|c|c|}
\hline Nama Validator & No. Butir Penilaian & Penilaian & Skor yang Diperoleh \\
\hline \multirow{4}{*}{} & 1 & SB & 4 \\
\cline { 2 - 4 } & 2 & SB & 4 \\
\cline { 2 - 4 } & 3 & SB & 4 \\
\cline { 2 - 4 } & 4 & SB & 4 \\
\cline { 2 - 4 } & 5 & SB & 4 \\
\cline { 2 - 4 } Drs. H. Sukron, \\
\cline { 2 - 4 } M.Pd & 6 & SB & 4 \\
\cline { 2 - 4 } & 7 & SB & 4 \\
\cline { 2 - 4 } & 8 & SB & 4 \\
\cline { 2 - 4 } & 9 & SB & 4 \\
\cline { 2 - 4 } & 10 & SB & 3 \\
\cline { 2 - 4 } & 11 & SB & 4 \\
\cline { 2 - 4 } & 12 & SB & 4 \\
\cline { 2 - 4 } & 13 & SB & 3 \\
\cline { 2 - 4 } & 14 & & 58 \\
\hline
\end{tabular}

\section{Tabel 8}

Skor dan Kategori Hasil Validasi RPP oleh ahli 2 


\begin{tabular}{|c|c|c|c|}
\hline Nama Validator & No. Butir Penilaian & Penilaian & Skor yang Diperoleh \\
\hline \multirow{15}{*}{$\begin{array}{l}\text { Avissa Purnama } \\
\text { Yanti, M.Pd }\end{array}$} & 1 & SB & 4 \\
\hline & 2 & SB & 4 \\
\hline & 3 & SB & 4 \\
\hline & 4 & SB & 4 \\
\hline & 5 & $\mathrm{~B}$ & 3 \\
\hline & 6 & SB & 4 \\
\hline & 7 & B & 3 \\
\hline & 8 & $\mathrm{~B}$ & 3 \\
\hline & 9 & SB & 4 \\
\hline & 10 & SB & 4 \\
\hline & 11 & SB & 4 \\
\hline & 12 & SB & 4 \\
\hline & 13 & SB & 4 \\
\hline & 14 & SB & 4 \\
\hline & 15 & SB & 4 \\
\hline \multicolumn{3}{|c|}{ Jumlah } & 57 \\
\hline \multirow{2}{*}{\multicolumn{3}{|c|}{$\frac{\text { Presentase Tingkat Kevalidan }}{\text { Kriteria Valid }}$}} & $95 \%$ \\
\hline & & & Valid \\
\hline
\end{tabular}

Berdasarkan Tabel 7 dan 8 di atas, secara keseluruhan RPP memperoleh skor 97\% dan 95\% dan memenuhi kriteria valid sehingga dapat digunakan dengan revisi. Hasil revisi yang telah dilakukan, selanjutnya dikonsultasikan kembali kepada ahli sampai diperoleh perangkat pembelajaran yang dikatakan layak dan dapat digunakan. Setelah dilakukan revisi, perangkat pembelajarannya kembali dinilai oleh masing-masing ahli.

\section{Validasi LKPD}

Validasi LKPD dilakukan oleh Ahli materi, yaitu bapak Bapak Drs. H. Sukron, M.Pd dari staf pengawas bidang pendidikan madrasah Kemenag Lampung dan Ibu Avissa Purnama Yanti, M.Pd dari Universitas Islam Negri Raden Intan Lampung. Adapun rekapitulasi hasil penilaian validator ahli materi terhadap LKPD diperoleh sebagai berikut:

\section{Tabel 9.}

Rekapitulasi Skor dan Kategori Hasil Validasi LKPD

\begin{tabular}{|l|l|l|l|}
\hline No & Nama Validator & Skror Validasi Materi & Skor Validasi Media \\
\hline 1 & Drs. H. Sukron, M.Pd & $91,67 \%$ (Valid) & $95 \%$ (Valid) \\
\hline 2 & Avissa Purnama Yanti, M.Pd & $94,44 \%$ (Valid) & $94 \%$ (Valid) \\
\hline
\end{tabular}

Berdasarkan Tabel 9 di atas, terlihat bahwa LKPD memperoleh skor validasi materi sebesar 91,67\% dan 94,44\% dengan kriteria valid. Adapaun validasi media teradap LKPD memperoleh skor 95\% dan 94\% dengan kriteria valid. Sehingga secara keseluruhan LKPD dapat digunakan dengan revisi. Hasil revisi yang telah dilakukan, selanjutnya dikonsultasikan kembali kepada ahli sampai diperoleh perangkat pembelajaran yang dikatakan layak dan dapat digunakan. Setelah dilakukan revisi, perangkat pembelajarannya kembali dinilai oleh masing-masing ahli. 
Pengembangan Model Creative Problem Solving (CPS) Untuk Meningkatkan Kemampuan Berpikir Reflektif Siswa, Ayu Devita Sari, Sri Hastuti Noer, Asmiati

\section{Validasi Praktisi terhadap Model, RPP, dan LKPD}

Langkah selanjutnya adalah validasi praktisi. Validasi praktisi terhadap Model, RPP, dam LKPD dilakukan oleh praktisi pendidikan, yaitu Ibu Anggih Ayu Nindyasari, S. Pd. dan Ibu Nindya Indah Pertiwi, S. Pd, Gr. Sebagi guru mata pelajaran matematika. Adapun rekapitulasi hasil penilaian validator ahli praktisi diperoleh sebagai berikut:

\section{Tabel 10}

Rekapitulasi Skor dan Kategori Hasil Validasi LKPD

\begin{tabular}{|c|c|c|c|}
\hline Nama Validator & Produk & Skror Model & Kriteria \\
\hline \multirow{3}{*}{$\begin{array}{c}\text { Anggih Ayu } \\
\text { Nindyasari, S. Pd }\end{array}$} & Model & $85,93 \%$ & Sangat praktis \\
\cline { 2 - 4 } & Silabus & $81,25 \%$ & Praktis \\
\cline { 2 - 4 } & RPP & $86,11 \%$ & Sangat praktis \\
\cline { 2 - 4 } & LKPD & $85 \%$ & Sangat praktis \\
\hline \multirow{3}{*}{$\begin{array}{c}\text { Nindya Indah } \\
\text { Pertiwi, S. Pd, Gr. }\end{array}$} & Model & $82,81 \%$ & Sangat praktis \\
\cline { 2 - 4 } & Silabus & $84,37 \%$ & Praktis \\
\cline { 2 - 4 } & RPP & $87,96 \%$ & Sangat praktis \\
\cline { 2 - 4 } & LKPD & $82,5 \%$ & Sangat praktis \\
\hline
\end{tabular}

Berdasarkan Tabel 10 tentang validasi praktisi di atas, terlihat bahwa keseluruhan produk memperoleh skor validasi dengan kriteria sangat praktis dan praktis. Sehingga secara keseluruhan produk dapat digunakan dalam pembelajaran.

Berdasarkan penilaian para ahli secara keseluruhan, maka secara teoritis model creative problem solving dapat menjadi alternatif pembelajaran yang dapat meningkatkan kemampuan berpikir siswa siswa. Secara keseluruhan, produk yang terdiri dari pengembangan model, silabus, RPP, LKPD, layak digunakan dalam proses pembelajaran.

\section{KESIMPULAN}

Berdasarkan hasil pengembangan dan penilaian validasi dari para ahli, maka pengembangan model creative problem solving beserta perangkat pedukung dinyatakan valid dan layak digunakan dalam proses pembelajaran. Secara teoritis, model creative problem solving diharapkan dapat meningkatkan kemampuan berpikir reflektif siswa kelas X pada materi SPLTV.

Berdasarkan kesimpulan di atas maka saran yang dapat dipertimbangkan, yaitu (1) Bagi guru, dapat menjadikan model creative problem solving sebagai alternatif untuk meningkatkan kemampuan berpikir reflektif siswa kelas X pada materi SPLTV; (2) Bagi peneliti berikutnya, diharapkan dapat melakukan penelitian lebih lanjut dengan model creative problem solving. 


\section{DAFTAR PUSTAKA}

Aris, S. (2014).68 Model Pembelajaran Inovatif Dalam Kurikulum 2013. Ar-Ruzz Media.

Bennett, N., Borg, W. R., \& Gall, M. D. (1984). Educational Research: An Introduction. British Journal of Educational Studies. https://doi.org/10.2307/3121583

Daties, M. (2010). Pengaruh Metode Pembelajaran Creative Problem Solving (CPS) terhadap Peningkatan Kemampuan Berpikir Kreatif Siswa. Universitas Pendidikan Indonesia.

Gokhale, A. A. (1996). Effectiveness of Computer Simulation for Enhancing Higher Order Thinking. Journal of Industrial Teacher Education.

Gurol, A. (2011). Determining the reflective thinking skills of pre-service teachers in learning and teaching process. Energy Education Science and Technology Part B: Social and Educational Studies.

Mayasari, P., Halim, A., \& Ilyas, S. (2013). Model Pembelajaran Creative Problem Solving Untuk Meningkatkan Penguasaan Konsep Dan Keterampilan Generik Sains Siswa SMP. Jurnal Pendidikan Sains Indonesia.

Nindiasari, H., Kusumah, Y. S., Sumarmo, U., \& Sabandar, J. (2014). PENDEKATAN METAKOGNITIF UNTUK MENINGKATKAN KEMAMPUAN BERPIKIR REFLEKTIF MATEMATIS SISWA SMA. Edusentris. https://doi.org/10.17509/edusentris.v1i1.136

Noer, S. H. (2009). Peningkatan kemampan berpikir kritis matematis siswa SMP melalui pembelajaran berbasis masalah. Seminar Nasional Matematika Dan Pendidikan Matematika Jurusan Pendidikan Matematika FMIPA UNY, 5 Desember 2009.

Noer, S. H. (2010). Peningkatan Kemampuan Berpikir Kritis, Kreatif dan Reflektif (K2R) Matematis Siswa SMP melalui Pembelajaran Berbasis Masalah. Universitas Pendidikan Indonesia Bandung.

Rasyid, M. A. (2017). Profil Berpikir Reflektif Siswa SMP dalam Pemecahan Masalah Pecahan Ditinjau dari Perbedaan Gender. Kreano, Jurnal Matematika Kreatif-Inovatif. https://doi.org/10.15294/kreano.v8i2.9849

Sabandar, J. (2013). Berpikir Reflektif. UPI.

Saminanto. (2011). Model Pembelajaran Creative Problem Solving Dengan Video Compact Disk Untuk Mencapai Kompetensi Dasar Dalam Pembelajaran Matematika Di Mts. Jurnal PHENOMENON. 